Обрані праці 5-ї міжнародної науково-технічної конференції з будівельних матеріалів, конструкцій та споруд «Проблеми надійності та довговічності інженерних споруд і будівель на залізничному транспорті», Харків,

23-24 квітня 2015 року

$$
\begin{aligned}
& \text { ОБРАНІ ПРАЦІ 5-Ї МЕЖНАРОДНӦ̈ НАУКОВО-ТЕХНІЧНӦ̈ }
\end{aligned}
$$

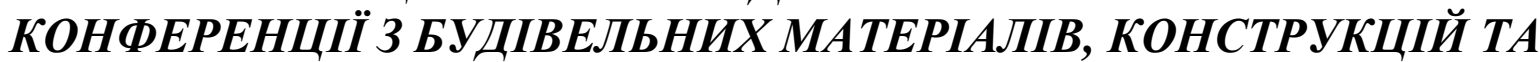

$$
\begin{aligned}
& \text { СПОРУД «ПРОБЛЕМИ НАДІЙНОСТІ ТА ДОВГОВІЧНОСТІ } \\
& \text { ІНЖЕНЕРНИХ СПОРУД І БУДІВЕЛЬ НА ЗАЛІЗНИЧНОМУ } \\
& \text { ТРАНСПОРТІ», ХАРКІВ, 23-24 КВІТНЯ } 2015 \text { РОКУ }
\end{aligned}
$$

УДК 620.92

\title{
ФІЗИКО-ХІМІЧНІ Й ТЕРМОДИНАМІЧНІ ОСНОВИ СИНТЕЗУ МІНЕРАЛІВ ТА ЇХ ГІДРАТАЦІЇ Й ДЕГІДРАТАЦІЇ ДЛЯ ОТРИМАННЯ ШТУЧНОГО КАМЕНЮ 3 ЗАДАНИМИ ВЛАСТИВОСТЯМИ
}

Д-р техн. наук К.К. Пушкарьова, д-р техн. наук Г.М. Шабанова

\begin{abstract}
ФИЗИКО-ХИМИЧЕСКИЕ И ТЕРМОДИНАМИЧЕСКИЕ ОСНОВЫ СИНТЕЗА МИНЕРАЛОВ И ИХ ГИДРАТАЦИИ И ДЕГИДРАТАЦИИ ДЛЯ ПОЛУЧЕНИЯ ИСКУССТВЕННОГО КАМНЯ С ЗАДАННЫМИ СВОЙСТВАМИ
\end{abstract}

Д-р техн. наук Е.К. Пушкарева, д-р техн. наук Г.Н. Шабанова

\section{PHYSICO-CHEMICAL AND THERMODYNAMIC FUNDAMENTALS OF SYNTHESIS OF MINERALS AND THEIR HYDRATION AND DEHYDRATION TO PRODUCE ARTIFICIAL STONE WITH GIVEN PROPERTIES}

DSc K.K. Pushkarova, DSc G.M. Shabanova

Встановлені нові фізико-хімічні закономірності синтезу, гідратаиії та дегідратаиії мінералів та їх склоподібних аналогів для отримання штучного каменю з заданими властивостями, у т.ч. високоміџного, жаростійкого. Сформульовані основні принииии його композиційної побудови, які дозволяють завдяки регулюванню фазового складу продуктів твердіння здійснити направлений синтез итучного каменю з прогнозованими термомеханічними характеристиками. Теоретично обтрунтовано можслиість створення нового класу барійвмісних цчементів поліфункиіонального призначення, щзо базується на прогнозуванні необхідних комбінацій фаз з урахуванням законів термодинаміки в прикладному застосуванні до фазових рівноваг багатокомпонентних барійвмісних оксидних систем. Встановлено, щзо основними продуктами їх гідратації $\epsilon$ гідроалюмінати, гідросилікати та гідроферити у кристалічному, криптокристалічному або аморфному станах, які в процесі твердіння утворюють високоміцчнй конгломерат.

Ключові слова: синтез міџності итучного каменю, прочеси гідратації та дегідратації; кристалохімічна подібність продуктів твердіння; барійвмісні иеементи.

Установлены новые физико-химические закономерности синтеза, гидратащии и дегидратации минералов и их стеклоподобных аналогов для получения искусственного камня с прогнозируемыми свойствами, в т.ч. высокопрочного, жаростойкого. Сформулировань принщипь его композищионного построения, позволяющие за счет регулирования фазового состава продуктов твердения осуществить направленный синтез искусственного камня с прогнозируемыми термомеханическими характеристиками. Теоретически обоснована возможность создания нового класса барийсодержащих ичементов полифункционального назначения, которая основана на прогнозировании необходимых комбиначий фаз с учетом законов термодинамики в прикладном применении их $к$ фазовым равновесиям 


\section{Обрані праці 5-ї міжнародної науково-технічної конференції з будівельних матеріалів, конструкцій та споруд «Проблеми надійності та довговічності інженерних споруд і будівель на залізничному транспорті», Харків,}

\section{3-24 квітня 2015 року}

многокомпонентных барийсодержащих оксидных систем. Установлено, что основными продуктами гидратаџии является гидроалюминаты, гидросиликаты и гидроферриты в кристаллическом, криптокристаллическом или аморфном состояниях, в процессе твердения которых образуется высокопрочный конгломерат.

Ключевые слова: синтез прочности искусственного камня, прочессы гидратации и дегидратации; кристаллохимическое подобие продуктов твердения; барийсодержащие иементы.

Installed new physical and chemical laws of synthesis, hydration and dehydration of minerals and glassy analogous for artificial stone with predetermined properties. It is shown that the optimal conditions for the synthesis strength of artificial stone created at forming a gel phase as a part of hydration products. A new approach to assessing the quality of artificial stone structure that takes into account the degree of crystal-chemical similarity for new products hydration at different stages of structures formation stone in a wide temperature range. Its proposed criterion of similarity crystal products hydration and dehydration that allowed to quantify the changing state of the stone structures at the elevated temperature.

Based on the developed ideas about the physical and chemical processes of hydration and dehydration of mineral binders formulated the basic principles of artificial stone composite construction with given properties, including high-strength, heat-resistant, which allows by adjusting the phase of hardening products implement directed synthesis of artificial stone predictable thermomechanical characteristics.

Theoretically proved the possibility of creating a new class of multifunctional purpose bariumcontent cements based on the prediction of the required combinations of phases, taking into account the laws of thermodynamics as applied to the use of phase equilibria of multicomponent systems. The features of the processes of hydration and hardening cements of bariumcontent new class and found that the main products of hydration are hidroaluminates, hydrosilicates and hydroferrous crystalline, criptocrystalline or amorphous states. Its phases take part in forming of structure high strength conglomerate.

Key words: synthesis of strength artificial stone, hydration and dehydration processes; cristalchemical similarity of hardening products; bariumcontent cements.

\section{Вступ}

Багаторівневий характер організації композиційних матеріалів необхідно враховувати як один 3 важливих факторів при направленому синтезі матеріалів 3 заданими експлуатаційними характеристиками [1]. Властивості всіх матеріалів, в тому числі бетонів, визначаються їх складом, структурою та технологією [2].

Аналіз відомої інформації [3] дозволяє зазначити, що одним з важливих показників якості структури $\epsilon$ мікроструктура, причому багато фахівців відмічають іï домінуючий вплив на властивості штучного каменю порівняно 3 іншими ієрархічними рівнями структури композита.

Відомо, що отримання оптимальної мікроструктури цементного каменю досягається як шляхом синтезу гідратних новоутворень заданого складу, так і шляхом керування швидкістю процесу гідратації на окремих їі стадіях, що забезпечує отримання необхідного співвідношення гелевидної та кристалічної фаз у складі продуктів твердіння [4]. Слід зазначати, що основні закономірності керування складом гідратних новоутворень повинні базуватись на результатах аналізу ступеня кристалохімічної подібності як вихідних фаз, так і продуктів їх гідратації з урахуванням можливості їх зрощення та перекристалізації 


\section{Обрані праці 5-ї міжнародної науково-технічної конференції з будівельних матеріалів, конструкцій та споруд «Проблеми надійності та довговічності інженерних споруд і будівель на залізничному транспорті», Харків,}

\section{3-24 квітня 2015 року}

з часом без розвитку значних деструктивних напружень [5]. Склад продуктів гідратації визначає не тільки розвиток міцнісних, але й спеціальних властивостей штучного каменю. Це положення є вірним при синтезі штучного композита 3 заданими характеристиками у будь-якій в'яжучій системі гідратаційного твердіння [6 ].

\section{Постановлення проблеми}

3 використанням сучасних уявлень будівельного матеріалознавства щодо встановлення взаємозв'язку «склад структура - процес - властивості» та фізико-хімічних основ регулювання процесами їх структуроутворення (як в умовах високотемпературного синтезу, так і підчас гідратації) досліджені фізико-хімічні закономірності процесів гідратації та дегідратації мінералів в системах: « $\mathrm{R}_{2} \mathrm{O}$ $\mathrm{CaO}-\mathrm{MgO}-\mathrm{Al}_{2} \mathrm{O}_{3}-\mathrm{SiO}_{2}-\mathrm{H}_{2} \mathrm{O}$ » та «CaO-BaO$\mathrm{MgO}-\mathrm{Al}_{2} \mathrm{O}_{3} \quad-\mathrm{Cr}_{2} \mathrm{O}_{3}$ » та визначені шляхи отримання ефективних матеріалів загальнобудівельного та спеціального призначення (в т.ч. високоміцних, жаростійких, вогнетривких, корозійностійких).

Для визначення принципової можливості формування високоміцного та жаростійкого каменю як об'єкти дослідження розглянуті фазові склади продуктів гідратації та дегідратації в'яжучих композицій в системі « $\mathrm{R}_{2} \mathrm{O}-\mathrm{CaO}-\mathrm{MgO}-\mathrm{Al}_{2} \mathrm{O}_{3}$ $\mathrm{SiO}_{2}-\mathrm{H}_{2} \mathrm{O}$ » та виконана оцінка кристалохімічної подібності продуктів гідратації та дегідратації мінеральних композицій як основного критерію, що передбачає отримання оптимальної структури композита 3 потрібними фізикомеханічними та термомеханічними характеристиками.

Для встановлення особливостей синтезу штучного каменю 3 наперед заданими властивостями досліджені процеси гідратації та дегідратації в системах: $\mathrm{CaO}-$ $\mathrm{Al}_{2} \mathrm{O}_{3} ; \quad \mathrm{CaO}-\mathrm{SiO}_{2} ; \quad \mathrm{CaO}-\mathrm{Al}_{2} \mathrm{O}_{3}-\mathrm{SiO}_{2} ; \mathrm{CaO}-$ $\mathrm{MgO}_{-} \mathrm{SiO}_{2} ; \quad \mathrm{CaO}-\mathrm{Al}_{2} \mathrm{O}_{3}{ }^{-} \quad \mathrm{MgO}_{-} \mathrm{SiO}_{2} \quad$ в присутності сполук лужних металів $(\mathrm{NaOH}$, $\left.\mathrm{Na}_{2} \mathrm{CO}_{3}, \quad \mathrm{Na}_{2} \mathrm{SiO}_{3}\right) . \quad$ В'яжучі композиції, замішані водою, були прийняті як аналоги порівняння.

\section{Методи досліджень}

При виконанні експериментальних робіт для вивчення вищенаведених систем були залучені наступні методи дослідження: рентгенофазовий аналіз (РФА), диференціально-термічний аналіз (ДТА), ІЧспектроскопічний (ІЧС), електронний парамагнітний резонанс (ЕПР), ядерний гама-резонанс (ЯГР), електронна та растрова мікроскопія. Також застосовано термодинамічний метод, який визначає енергетичну можливість i напрямок протікання реакцій, супроводжуючі їх теплові зміни, що дозволяє розраховувати теплові баланси процесів, а також встановлювати перевагу реакцій і стійкість сполук, що утворюються, шляхи подавлення небажаних реакцій i усунення побічних продуктів, вибір оптимального режиму протікання реакцій (температури, тиску i концентрації реагуючих речовин).

\section{Результати досліджень}

Як було доведено попередніми дослідженнями [7], синтез міцності штучного каменю гідратаційного твердіння визначається двома основними факторами: хімічною природою в'яжучих речовин та ступенем їх кристалохімічної подібності. За результатами проведених досліджень останній фактор стає особливо важливим при визначенні умов формування жаростійкого каменю в процесі дегідратації в'яжучих композицій, оскільки міцність структури каменю при дії температури в значній мірі визначається характером процесів дегідратації, що відбуваються, а також ступенем кристалохімічної подібності новоутворень на різних стадіях виготовлення штучного композиту.

Оцінка ступеня структурної відповідності продуктів гідратації та дегідратації можлива за допомогою кристалохімічного критерію подібності, розрахунок якого здійснено на припущенні, що зрощення кристалів іде за схемою РуайєФріделя вздовж плоских сіток, що ідентичні 


\section{Обрані праці 5-ї міжнародної науково-технічної конференції з будівельних матеріалів, конструкцій та споруд «Проблеми надійності та довговічності інженерних споруд і будівель на залізничному транспорті», Харків,}

\section{3-24 квітня 2015 року}

за формою і приблизно рівні за розмірами. Для оцінки ступеня порушення міцності штучного каменю запропоновано коефіцієнт ступеня деструкції каменю при термічній обробці, який визначається як відношення величин критеріїв подібності продуктів гідратації та дегідратації [7].

Як показали результати фізикомеханічних та фізико-хімічних досліджень оптимальні умови для синтезу міцності в системі «оксид кальцію-оксид алюмініюлужний компонент» створюються при гідратації низькоосновних алюмінатів кальцію $\mathrm{CA}$ та $\mathrm{CA}_{2}$ в присутності розчинних силікатів натрію. Ці композиції були використані як моделі для розробки високоміцних та жаростійких матеріалів, що відрізняються прискореним зростанням міцності у часі $\mathrm{i}$ незначним зниженням міцності при експлуатації в діапазоні температур $600 \ldots 1200^{\circ} \mathrm{C}$ (a.c. СРСР № 998410). На базі цих композицій розроблені матеріали спеціального призначення, в тому числі:

- зносо- та термостійкі композити, що отримані на основі глиноземистих та високоглиноземистих лужних цементів 3 добавками карбіду кремнію (термостійкість 90...100 циклів водних теплозмін, зносостійкість у $2 \ldots 2,5$ рази вище за зносостійкість контрольних зразків на основі високоглиноземистого цементу);

отримані

жаростійкі композиційні матеріали класів И12-И13 на основі лужних алюмінатних цементів та хромомагнезіальних добавок, що характеризуються міцністю при стиску 50...70 МПа, залишковою міцністю після випалювання при $\mathrm{T}=1000^{\circ} \mathrm{C}-60 \ldots 80 \%$; термостійкістю 27...69 теплозмін.

В системі « $\mathrm{CaO}-\mathrm{SiO}_{2}$-лужний компонент» оптимальні умови для синтезу міцності штучного каменю при його твердінні у широкому діапазоні температур створюються при гідратації мінералу $\beta-\mathrm{C}_{2} \mathrm{~S}$ у присутності $\mathrm{Na}_{2} \mathrm{SiO}_{3}$, причому наявність іонів лужних металів активізує не тільки процеси гідратації, але й сприяє стабілізації структури випаленого каменю, усуваючи можливі в цій системі модифікаційні перетворення і створюючи тим самим умови для синтезу ефективних жаростійких матеріалів.

Розглянуті модельні системи використані для отримання композиційних матеріалів спеціального призначення (а.c. СРСР 1043123; 1121249; 1277560).

На основі техногенної сировини, що містить мінерали $\beta-\mathrm{C}_{2} \mathrm{~S}$, та дегідратовані цеолітові породи отримані жаростійкі композити, що є стійкими до газової корозії $\left(\mathrm{CO}, \mathrm{CO}_{2}, \mathrm{O}_{2}\right)$. Випробування проведені за стандартом ASTM C 288-78. Встановлено, що міцність таких матеріалів зростає у 1,4 рази, зміна пористості не перевищує $16 \%$, в той час як для відомих аналогів має місце зниження міцності у 2,5 рази та зміна пористості перевищує $25 \%$.

Згідно результатам багаторічних досліджень [5] моделювання процесів отримання алюмосилікатних композицій у системі $\quad$ $\mathrm{CaO}-\mathrm{Al}_{2} \mathrm{O}_{3}-\mathrm{SiO}_{2}$-лужний компонент» відкриває широкі перспективи синтезу матеріалів на основі металургійних шлаків, природних та техногенних стекол, причому алюмосилікатні в'яжучі системи відрізняються суттєвими перевагами, такими як: підвищення міцності після нагрівання їх до робочої температури; висока реакційна здатність при термічній обробці, що дозволяє за рахунок введення модифікуючих добавок керувати структурою штучного каменю, a також існує можливість регулювання вогнетривкістю та термомеханічними характеристиками матеріалу шляхом зміни кремнеземистого та лужного компонентів. Наведені дані обумовлюють економічну та технічну доцільність використання алюмосилікатних систем, в тому числі у вигляді шлаколужних цементів, для отримання жаростійких композитів.

Регулювання термомеханічних характеристик цементного каменю можливо шляхом введення до його складу алюмосилікатних добавок, наприклад, 


\section{Обрані праці 5-ї міжнародної науково-технічної конференції з будівельних матеріалів, конструкцій та споруд «Проблеми надійності та довговічності інженерних споруд і будівель на залізничному транспорті», Харків,}

\section{3-24 квітня 2015 року}

шамоту (а.c. СРСР 730650). При збільшенні кількості цієї добавки ступінь зменшення міцності каменю при дії температурного фактора знижується. Досягнутий ефект обумовлений направленим синтезом у складі продуктів твердіння низькоосновних гідросилікатів кальцію та лужнолужноземельних гідроалюмосилікатів. На основі модифікованих шлаколужних в'яжучих систем 3 використанням шлакопемзових та шамотних заповнювачів отримані жаростійкі композити, міцність яких складає $15 . .40$ МПа. Після випалювання при $\mathrm{T}=800^{\circ} \mathrm{C}$ міцність таких бетонів у 1,2...1,7 разів перевищує міцність бетону без добавок, а термостійкість збільшується у $1,5 \ldots 3$ рази.

Регулювання

термомеханічних властивостей шлаколужного бетону можливо також шляхом введення як модифікуючих добавок алюмінатів кальцію $\mathrm{CA}$ та $\mathrm{CA}_{2}$ або алюмотермічних шлаків, що ï містять. Згідно результатам проведених досліджень висока швидкість набору міцності (7 діб - 90 МПа, 28 діб - 120 МПа) обумовлена утворенням при гідратації алюмінатів кальцію висококремнеземистих гідрогранатів та лужних гідроалюмосилікатів, подібних до анальциму, які $\epsilon$ центрами кристалізації гелевидної фази, що утворюються у великій кількості при замішуванні шлаку розчинами лужних компонентів. Результати фізикомеханічних випробувань констатують не тільки високі міцнісні показники отриманого штучного каменю, але й високу залишкову міцність зразків після випалювання, що досягає $115 \ldots 120 \%$.

\section{Таким}

чином,

отримання високоміцних та жаростійких композитів в системі «СaO- $\mathrm{Al}_{2} \mathrm{O}_{3}-\mathrm{SiO}_{2}$-лужний компонент» та керування їх властивостями досягається шляхом направленого формування в складі продуктів твердіння лужно-лужноземельних

гідроалюмосилікатів, які сприяють плавному протіканню процесів дегідратації без виникнення

суттєвих

деструктивних напружень в структурі штучного каменю.

Встановлені закономірності формування фазового складу продуктів гідратації та дегідратації в системі «оксид кальцію - оксид магнію - оксид силіцію лужний компонент» визначили шляхи направленого синтезу цементів спеціального призначення із залученням відходів металургійної та електрохімічної промисловості. Жаростійкі в'яжучі системи, модифіковані добавками магнійсилікатних порід, $\epsilon$ перспективними цементами для отримання на їх основі жарокорозійностійких композитів, в тому числі теплоізоляційних сумішей для виготовлення корозійностійких виробів до дії розплавлених металів. Середня густина отриманого матеріалу (при використанні як теплоізоляційного наповнювача каолінового волокна) не перевищує $390 \mathrm{\kappa г} / \mathrm{m}^{3}$, а міцність при твердінні становить $3 . . .4$ МПа, коефіцієнт теплопровідності - $(7,33 . .9,52)$ • $10^{-2} \mathrm{BT} /(\mathrm{м} \cdot \mathrm{K})$. Висока активність в'яжучої речовини забезпечує добре зчеплення каолінових волокон та сприяє підвищенню хімічної стійкості отриманого теплоізоляційного матеріалу при взаємодії 3 розплавом алюмінію. Залишкова міцність зразків після взаємодії 3 розплавом, температура якого становила $700 \ldots 1000^{\circ} \mathrm{C}$, досягає 93...95\%. Високі експлуатаційні властивості отриманих теплоізоляційних сумішей дозволили використати їх для футерування металопровода МГД-насосів (a.c.CPCP 1017693).

Встановлені закономірності впливу хіміко-мінералогічного складу вихідних композицій на склад продуктів гідратації та дегідратації мінеральних в'яжучих систем, а також ступеня кристалохімічної подібності новоутворень на різних стадіях формування штучного каменю, були покладені в основу синтезу жаростійких матеріалів 3 регульованими фізико-механічними та термо-механічними характеристиками (а.c. СРСР 775070; 1315409; 1418325; 4474120). Використання методів направленого синтезу 


\section{Обрані праці 5-ї міжнародної науково-технічної конференції з будівельних матеріалів, конструкцій та споруд «Проблеми надійності та довговічності інженерних споруд і будівель на залізничному транспорті», Харків,}

\section{3-24 квітня 2015 року}

заданого фазового складу продуктів гідратації та дегідратації у поєднанні 3 кристалохімічним аналізом новоутворень на різних стадіях твердіння каменю дозволило розробити науковий підхід, що забезпечує отримання широкої гами матеріалів поліфункціонального призначення, в тому числі високоміцих, жаростійких та жарокорозійностійких бетонів та захисних i вогнестійких покриттів із залученням у сферу виробництва відходів різних галузей народного господарства.

Розвиток нової техніки, який пов'язано 3 використанням високих температур, вимагає нових, більш ефективних матеріалів, в тому числі вогнетривких цементів і бетонів на їх основі. 3 цієї точки зору розробка нових складів в'яжучих матеріалів спеціального призначення 3 комплексом заданих цінних експлуатаційних характеристик: підвищеною міцністю, вогнетривкістю, стійкістю до дії агресивних факторів, $€$ актуальною проблемою, оскільки сприяє розширенню галузей застосування бетонів, торкрет-мас і сухих сумішей, отриманих на основі таких матеріалів.

Вирішити дану проблему можливо шляхом створення шпінельних цементів, мінералогічний склад яких характеризується наявністю алюмомагнезіальної $\left(\mathrm{MgAl}_{2} \mathrm{O}_{4}\right)$ або хромомагнезіальної $\left(\mathrm{MgCr}_{2} \mathrm{O}_{4}\right)$ шпінелі, які можна віднести до низькоосновних важкорозчинних сполук (НВРС), а також алюмінатів лужноземельних елементів, які $є$ носіями гідравлічної активності. Шпінельні цементи відносяться до високовогнетривких, швидкотвердіючих та високоміцних в'яжучих речовин.

На основі аналітичних досліджень проведено високотемпературний синтез шпінельвмісних цементів у вищезазначених системах та отримані гідравлічні в'яжучі матеріали 3 низьким водоцементним відношенням $(0,16-0,27), \quad$ які $\epsilon$ швидкосхоплючимися, швидкотужавіючими (міцність у віці 1 доби складає 25-40 МПа) 3 високими показниками міцності у віці 28 діб тверднення 50 - 100 МПа.

Низьке водоцементне відношення пояснюється змочуванням при взаємодії цементу 3 водою, відбуваються процеси хемосорбції. Поверхня алюмінатної фази заряджена позитивно [18, 19], на її поверхні утворюються сольватні оболонки та позитивні електричні заряди, між якими виникають сили відштовхування. Атоми поверхні НВРС мають вільні орбіталі, які здатні до донорно-акцепторної взаємодії 3 молекулами води, що призводить до позитивно зарядженої поверхні НВРС.

Заряди, які забезпечують взаємне відштовхування часток алюмінатної фази в розчині сконцентровані, між ними виникають сили притягання, тому що на гострих краях цементних зерен товщина сольватної оболонки менша, ніж на інших ділянках поверхні, тому i щільність електростатичного заряду менше, i, як висновок, сила відштовхування менше. У поверхневих іонів НВРС, із-за розірваних валентностей, не дістає іонів $\mathrm{O}^{-2}$, які мають донорні властивості, тому у присутності води відбувається насичення вільних валентностей, за рахунок переходу протонів від $\mathrm{H}_{2} \mathrm{O}$ к $\mathrm{O}^{-2}$ та утворення гідроксидних іонів на поверхні НВРС. Таким чином, утворюються плівки, які заважають виходу дислокацій на поверхню при деформуванні і тим самим призводять до зміцнення. У лужних розчинах ці гідроксиди мають здібність до катіонообміних властивостей 3 гідроксидами лужноземельних елементів.

Методом атомної адсорбції встановлено, що поверхня НВРС в $4-5$ разів більш активна із розчину моноалюмінату катіону лужноземельного елементу, ніж комплексні аніони алюмінію за перші 24 години. Цей факт вказує на то, що утворення адгезійних контактів на границі «НВРС цементуюча фаза» відбувається за рахунок кислотно-основної взаємодії катіонів лужноземельного елемента цементуючої фази та поверхневих шарів $\mathrm{OH}^{-}$груп НВРС. 


\section{Обрані праці 5-ї міжнародної науково-технічної конференції з будівельних матеріалів, конструкцій та споруд «Проблеми надійності та довговічності інженерних споруд і будівель на залізничному транспорті», Харків,}

\section{3-24 квітня 2015 року}

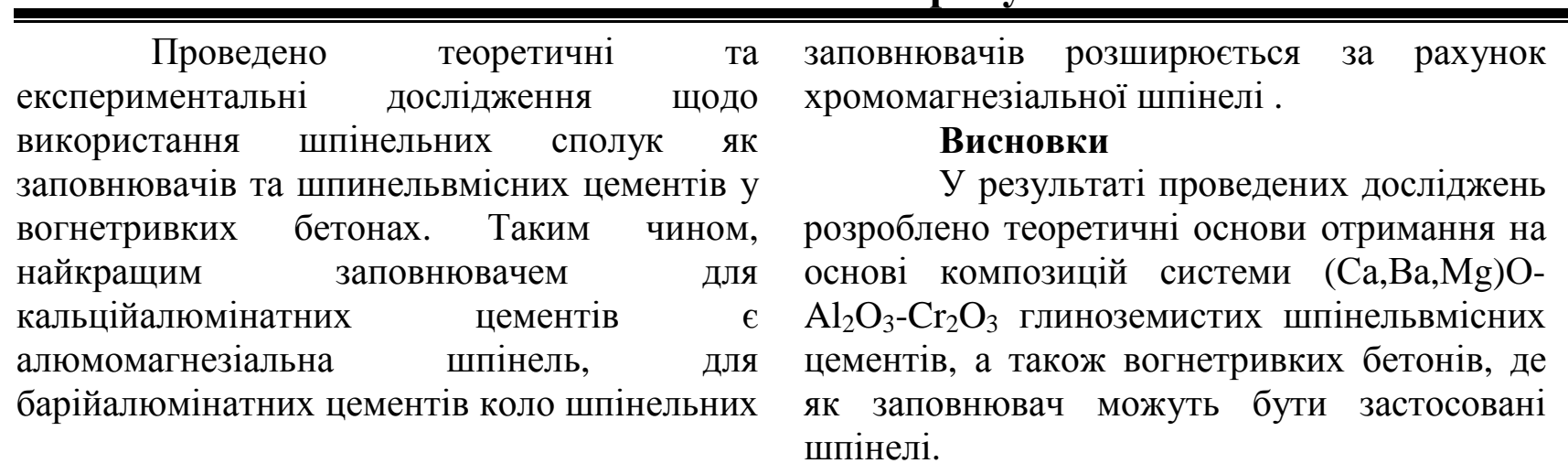

\section{Список використаних джерел}

т.1.- $286 \mathrm{c}$.

1. Круглицкий Н.Н. Основы физико-химической механики.- К., Вища школа, 1975.-

2. Мчедлов-Петросян О.П. Химия неорганических строительных материалов.- М.: Стройиздат, 1988.- 304 с

3. Грушко И.М., Ильин А.Г., Чихладзе Э.Д. Повышение прочности и выносливости бетона.- К.: Вища школа, 1986.- 149 с.

4. Тимашев В.В. Избранные труды.- М.: Стройиздат, 1986.- 424 с.

5. Пушкарева Е.К. Синтез искусственного камня с заданными свойствами на основе щелочно-щелочноземельных вяжущих систем . Автореферат дис. на соиск. уч. ст.к.т.н., К., 1985.- $16 \mathrm{c.}$

6. Шпынова Л.Г., Илюхин В.В., Саницкий М.А. Кристаллохимический аспект гидратационной активности цементных минералов // Изв. АН ССР, Неорганические материалы. - 1985. - 21.- №10.- с.1786-1789.

7. Пушкарьова К.К. Жаростійкі матеріали на основі лужних вяжучих систем. Автореферат дис. на здобуття вч. ст. д.т.н., Харків, 1995- 32с.

8. Шабанова Г.Н. Барийсодержащие оксидные системы и вяжущие материалы на их основе / Г.Н. Шабанова - Х.: НТУ «ХПИ», 2006. - 280 с.

Пушкарьова Катерина Костянтинівна, д.т.н., проф., зав. кафедри будівельних матеріалів, Київський національний університет будівництва і архітектури; Тел.(066) 153 80 53, E-mail: sribm_pushkarova@mail.ru

Шабанова Галина Миколаївна, д.т.н., проф., гол. наук. співр. кафедри технології кераміки, вогнетривів, скла та емалі, Національний технічний університет «Харківський політехнічний інститут»; Тел.(050) 90653 80, E-mail: gala-shabanova@yandex.ru

Pushkarova Katerina K., DSc, Prof, Head of Building Materials Dept, Kiiv National University of Construction and Architecture, Teл.(+38 066) 15380 53, E-mail: sribm_pushkarova@mail.ru

Shabanova Galina M., DSc, Prof, Chief Researcher of the Technology of ceramics, refractories, glass and enamel Dept; Tel.(+38 050) 90653 80,E-mail: gala-shabanova@yandex.ru

Стаття прийнята 25.05.2015 p 